\title{
PENGARUH MODEL PEMBELAJARAN KONTEKSTUAL, PEMBELAJARAN LANGSUNG DAN MOTIVASI BERPRESTASI TERHADAP HASIL BELAJAR KOGNITIF
}

\author{
Edy Suprapto \\ Pendidikan Teknik Mesin \\ FKIP Universitas Nusa Cendana \\ edysuprapto93@yahoo.co.id
}

\begin{abstract}
Abstrak. Penelitian ini bertujuan: (1) menguji perbedaan hasil belajar kognitif antara siswa yang diajar dengan model pembelajaran kontekstual dan pembelajaran langsung, (2) menguji perbedaan hasil belajar kognitif antara siswa dengan motivasi berprestasi tinggi dan siswa dengan motivasi berprestasi rendah, dan (3) menguji ada tidaknya interaksi antara model pembelajaran dan motivasi berprestasi terhadap hasil belajar kognitif. Penelitian ini menggunakan model rancangan nonequivalent control group design dengan rancangan faktorial $2 \times 2$. Subjek penelitian adalah siswa SMK Negeri 2 Kupang, kelas X TKR yang memprogram pelajaran sepeda motor semester ganjil tahun 2013/2014. Subjek penelitian tidak ditentukan secara random tapi secara intact group, yaitu kelas X TKR 1 (38 siswa) sebagai kelas eksperimen (pembelajaran kontekstual) dan kelas X TKR 2 (39 siswa) sebagai kelas kontrol (pembelajaran langsung). Data penelitian dianalisis secara deskriptif dan ANOVA (Analysis of Variance) yang didasarkan pada taraf signifikansi 5\%. Dari hasil penelitian disimpulkan: (1) penggunaan model pembelajaran kontekstual lebih unggul dibandingkan dengan model pembelajaran langsung terhadap hasil belajar kognitif, (2) ada perbedaan hasil belajar kognitif yang signifikan antara siswa dengan motivasi berprestasi tinggi dan siswa dengan motivasi berprestasi rendah, dan (3) tidak ada interaksi yang signifikan antara model pembelajaran dan motivasi berprestasi pada hasil belajar kognitif.
\end{abstract}

Kata kunci: model pembelajaran kontekstual, model pembelajaran langsung, motivasi berprestasi, hasil belajar kognitif.

\begin{abstract}
The purposes of this study were: (1) to investigate the difference of achievement among students who were instructed by using contextual instructional models and direct instructions, (2) to investigate the cognitive achievement among students with high motivation achievement and low motivation achievement, and (3) to investigate whether there is an interaction or not between instructional models and motivation achievement on cognitive achievement. This study applied factorial 2x2 design with Nonequivalent Control Group Design. The research subjects were students joining motor cycle course at odd semester in year 2013-2014, they were 77 students selected and grouped based on the classes, they were from X TKR-1 (38 students) treated as the experiment class, and X TKR-2 (39 students) treated as control class. The main data of the study was analyzed with ANOVA using SPSS for Windows version 17.00. The findings showed that: (1) the use of contextual instruction was better that direct instruction on cognitive achievement, (2) there was a significant difference on cognitive achievement between students with high motivation achievement and students with low motivation achievement, and (3) there was no significant interaction between model of instruction and motivation achievement on cognitive achievement
\end{abstract}

Key words: contextual instruction model, direct instruction model, motivation achievement, cognitive achievement

\section{PENDAHULUAN}

Proses belajar dan pembelajaran merupakan kegiatan yang direncanakan dan dilakukan secara sadar serta mempunyai tujuan tertentu. Aktivitas belajar terutama terpusat pada pebelajar (siswa), sedangkan pembelajar (guru) lebih banyak berfungsi sebagai motivator dan fasilitator terjadinya belajar. Kriteria 
terjadinya belajar pada diri pebelajar adalah terjadinya perubahan atau 11 pertambahan pengetahuan, keterampilan dan sikap (Hitipeuw, 2009). Untuk mengetahui besarnya perubahan pengetahuan, keterampilan dan nilai sikap pada pebelajar perlu dilakukan pengukuran secara otentik oleh seorang pembelajar. Hasil pengukuran yang dilakukan pembelajar tersebut dapat berupa nilai atau dalam bentuk yang lain, yang semuanya merupakan output atau hasil belajar dari pebelajar, yang meliputi domain kognitif, perkembangan emosional, dan sosial (Ahmadi et al., 2011). Dalam pembelajaran kontekstual, hasil belajar diukur sepanjang proses pembelajaran dengan berbagai macam strategi penilaian, yaitu: portofolio, kinerja, proyek, dan tes (Johnson, 2002). Oleh karena itu, hasil belajar adalah kecakapan nyata pebelajar yang diperoleh dari proses belajar, yang dalam hal ini difokuskan pada hasil belajar kognitif

Untuk meningkatkan kompetensi pengetahuan dan keterampilan para pebelajar dilakukan melalui proses pembelajaran, guna memberikan bekal yang memadai dalam kehidupan nyata di masyarakat. Namun, kenyataannya masih sering dijumpai kualitas hasil pembelajaran belum memenuhi kompetensi yang dibutuhkan, khususnya pada Sekolah Menengah Kejuruan (SMK) Teknologi. Rendahnya kualitas hasil pembelajaran ini, menurut Sumarna (2004) dikarenakan, adanya kecenderungan pembelajaran di kelas yang tidak berusaha mengaitkan konten pelajaran dengan kehidupan sehari-hari, sehingga pebelajar tidak mampu mengaplikasikan pengetahuannya dalam kehidupan nyata. Hal ini senada dengan pernyataan Ridwan (2008), bahwa selama ini pembelajaran pada pendidikan teknik dan kejuruan terkesan masih berorientasi teacher centred learning, mekanistis, berbasis konten dan belum sepenuhnya memberikan kesempatan pada siswa untuk mengembangkan pengetahuan dan keterampilan secara langsung dalam penemuanpenemuan berbasis konteks kehidupan nyata. Persiapan mengajar dirancang oleh guru secara testruktur dan materi ajar disampaikan sesuai dengan alokasi waktu yang ditetapkan, tanpa memperhatikan pemahaman yang dicapai siswa. Karena keterbatasan waktu di kelas, sering kali siswa kehilangan kesempatan untuk bertanya atau mendiskusikan materi pelajaran yang belum dipahami. Hal ini, sesuai dengan hasil penelitian Mukhadis (2003), yang menunjukkan 68,19\% kesulitan belajar disebabkan oleh kurangnya waktu yang tersedia. Siswa lebih banyak 
memahami pelajaran dari buku catatan, sehingga belum secara optimal mengembangkan kemampuan berpikir kritis dan kreatif dalam pemecahan masalah. Secara lebih spesifik, rendahnya kualitas hasil pembelajaran, khususnya pada pelajaran sepeda motor, dikemukakan dari hasil penelitian Banuarli (2012) dan Asyto (2013), yang menyatakan fenomena dilapangan terlihat bahwa hasil belajar siswa masih rendah dalam hal ini masih banyak siswa yang belum tuntas dalam pembelajaran sepeda motor sesuai dengan KKM yang telah ditentukan. Oleh karena itu, dalam rangka meningkatkan kualitas pembelajaran, khususnya di SMK, timbul wacana perlunya penambahan pendidikan satu tahun bagi lulusan SMK untuk magang di Industri atau Politeknik. Hal ini dimaksudkan untuk meningkatkan kompetensi yang dianggap masih belum memadai untuk masuk dunia kerja (Nuh, 2011).

Menyikapi keprihatinan para pakar pendidikan, mengenai rendahnya mutu pendidikan, khusus SMK, sudah seharusnya dijadikan pijakan untuk mereorientasi proses pembelajaran. Pandangan dan perilaku yang menempatkan pembelajaran sebagai content transmission model harus sudah ditinggalkan. Paradigma pembelajaran harus menekankan pada pembelajaran yang terpusat pada siswa (student centred learning), yaitu bergeser dari "guru dan apa yang akan diajarkan" ke arah "siswa dan apa yang akan dilakukan". Pembelajaran harus menciptakan hubungan yang bermakna (meaningful connections) dengan kehidupan nyata. Pembelajaran harus memberikan kesempatan yang luas kepada siswa untuk beraktivitas, baik minds-on activities maupun hand-on activities. Salah satu pendekatan pembelajaran yang dibangun dengan prinsip-prinsip seperti di atas, dan mempunyai perhatian terhadap upaya-upaya implementasi dalam kehidupan nyata adalah pembelajaran kontekstual (contextual teaching and learning [CTL]). Pembelajaran kontekstual adalah pembelajaran yang berusaha mengaitkan konten mata pelajaran dengan situasi dunia nyata dan memotivasi siswa untuk menghubungkan pengetahuan yang dimiliki dengan kehidupan mereka sehari-hari (Johnson, 2002). Untuk mewujudkan pembelajaran yang memiliki karakteristik seperti di atas, proses pembelajaran harus menekankan pada: making meaningful connection, constructivism, inquiry, critical and creative thinking, learning community, dan using authentic assessment. 
Berdasarkan uraian di atas, dapat diketahui bahwa pembelajaran kontekstual akan mendorong pebelajar memahami hakekat, makna, dan manfaat belajar, sehingga memungkinkan mereka rajin belajar dan termotivasi untuk senantiasa belajar. Hal tersebut sangat beralasan, karena materi pembelajaran kontekstual diperoleh dari pengalaman kehidupan para pebelajar. Para ahli beranggapan bahwa, pembelajaran kontekstual merupakan salah satu model pembelajaran yang inovatif, karena konsep model pembelajaran ini selalu menghubungkan antara pengalaman kehidupan nyata pebelajar dengan materi yang diajarkan, sehingga membantu pebelajar untuk menemukan sendiri hakekat dan makna belajar. Akibatnya, pebelajar mempunyai motivasi belajar yang tinggi yang pada akhirnya dapat meningkatkan hasil belajarnya. Hasil belajar dalam proses pembelajaran, menurut Bloom, meliputi ranah (domain) kognitif, psikomotorik, dan afektif (Krathwohl et.al., 1964). Karena luasnya permasalahan yang ada, maka dalam penelitian ini, hasil belajar hanya difokuskan pada hasil belajar kognitif.

Pembelajaran kontekstual dapat diimplementasikan dengan beberapa macam strategi pembelajaran, namun dalam penelitian ini digunakan strategi pembelajaran berbasis masalah (PBM) untuk mengimplementasikan pembelajaran kontekstual (Bern \& Erickson (2001), Efendi (2009), dan Komalasari (2012). Hal ini sejalan dengan hasil penelitiannya Frank \& Barzilai (2006), dengan pembelajaran kontekstual, pebelajar akan mendapatkan pengetahuan/teknik interdisipliner serta menggunakan analisis dan pertimbangan optimal untuk menghasilkan lebih dari satu alternatif penyelesaian masalah desain/rekayasa teknik dan dapat merasakan pentingnya kerja sama tim. Kemudian menurut Fong Ma et al. (2008), pembelajaran berbasis masalah akan dapat mendorong pebelajar memperoleh pengetahuan yang mereka butuhkan sebelum praktek. Dengan masalah yang otentik dan didukung oleh media yang bervariasi maka akan dapat membantu menjembatani kesenjangan antara teori dan praktek serta mendorong untuk belajar mandiri yang akhirnya belajar seumur hidup. Selanjutnya, Kelley \& Kelam (2009), menyebutkan pembelajaran kontekstual dengan pendekatan strategi pembelajaran berbasis masalah dan pembelajaran berbasis proyek akan dapat membekali pebelajar dengan kemampuan berpikir kritis yang sangat dibutuhkan untuk menghadapi berbagai macam masalah, sehingga memungkinkan pebelajar 
dapat beradaptasi bila bekerja di masyarakat (pabrik, peternakan, kantor dan lainlain) atau berwirausaha.

Berdasarkan uraian di atas maka tujuan penelitian dalam tulis ini adalah sebagai berikut: (1) menguji perbedaan hasil belajar kognitif antara siswa yang diajar dengan model pembelajaran kontekstual dan pembelajaran langsung, (2) menguji perbedaan hasil belajar kognitif antara siswa dengan motivasi berprestasi tinggi dan siswa dengan motivasi berprestasi rendah, dan (3) menguji ada tidaknya interaksi antara model pembelajaran dan motivasi berprestasi pada hasil belajar kognitif.

\section{METODE}

Penelitian ini menggunakan rancangan penelitian quasi experimental dengan model rancangan nonequivalent control group design (Tuckman, 1999). Oleh karena itu, dalam penelitian ini menggunakan kelompok utuh (intact group), yaitu siswa kelas X TKR (Teknik Kendaraan Ringan) semester satu yang memprogram pelajaran sepeda motor tahun 2013/ 2014. Jumlah siswa kelas X TKR 1 ada 38 orang, dan kelas X TKR 2 ada 39 orang. Untuk menentukan kelompok eksperimen dan kelompok kontrol ditentukan dengan cara diundi.

Penelitian ini menggunakan rancangan faktorial $2 \times 2$, yang dapat memberikan perlakuan/manipulasi dua variabel bebas atau lebih pada waktu bersamaan. Hal ini dilakukan untuk melihat efek masing-masing variabel bebas secara terpisah dan efek yang terjadi akibat adanya interaksi beberapa variabel. Kemudian, untuk menganalisis data digunakan teknik ANOVA (Analysis Of Variance) (Tuckman, 1999 \& Kerlinger et al, 2000). Model rancangan penelitian yang digunakan adalah nonequivalent control group design, seperti gambar 1.

\begin{tabular}{llll}
\hline $\mathbf{O}_{1}$ & $\mathbf{X}_{1}$ & $\mathbf{Y}_{1}$ & $\mathbf{O}_{2}$ \\
\hline $\mathbf{O}_{3}$ & $\mathbf{X}_{2}$ & $\mathbf{Y}_{1}$ & $\mathbf{O}_{4}$ \\
\hline $\mathbf{O}_{5}$ & $\mathbf{X}_{1}$ & $\mathbf{Y}_{2}$ & $\mathbf{O}_{6}$ \\
\hline $\mathbf{O}_{7}$ & $\mathbf{X}_{2}$ & $\mathbf{Y}_{2}$ & $\mathbf{O}_{8}$
\end{tabular}

Gambar 1. Model Rancangan Nonequivalent Control Group Design (diadaptasi dari Tuckman, 1999)

Keterangan:

$$
\mathrm{O}_{1}, \mathrm{O}_{3}, \mathrm{O}_{5}, \mathrm{O}_{7}=\text { Pretest }
$$




$$
\begin{array}{ll}
\mathrm{O}_{2}, \mathrm{O}_{4}, \mathrm{O}_{6}, \mathrm{O}_{8} & =\text { Posttest } \\
\mathrm{X}_{1} & =\text { Model pembelajaran kontekstual } \\
\mathrm{X}_{2} & =\text { Model pembelajaran langsung } \\
\mathrm{Y}_{1} & =\text { Motivasi berprestasi tinggi } \\
\mathrm{Y}_{2} & =\text { Motivasi berprestasi rendah } \\
& =\text { Kelompok utuh (intact group). }
\end{array}
$$

Tabel 1. Rancangan Faktorial 2x2.

\begin{tabular}{|c|c|c|l|}
\cline { 3 - 4 } \multicolumn{2}{c|}{} & \multicolumn{2}{c|}{ Model Pembelajaran } \\
\cline { 3 - 4 } \multicolumn{2}{c|}{} & \multicolumn{1}{c|}{ Kontekstual } & Pembelajaran Langsung \\
\hline Motivasi & Rendah & $Y_{1.1 .1}, Y_{1.1 .2}, Y_{1.1 . n}$ & $Y_{2.1 .1}, Y_{2.1 .2}, Y_{2.1 . n}$ \\
\cline { 2 - 4 } Berprestasi & Tinggi & $Y_{1.2 .1}, Y_{1.2 .2}, Y_{1.2 . n}$ & $Y_{2.2 .1}, Y_{2.2 .2}, Y_{2.2 . n}$ \\
\hline
\end{tabular}

Keterangan: $\mathrm{Y}=$ Hasil belajar kognitif dan keterampilan motorik

$$
\mathrm{n}=\text { Subjek ke } \mathrm{n}
$$

Hubungan antar variabel-variabel dalam penelitian ini dapat digambarkan sebagai berikut:

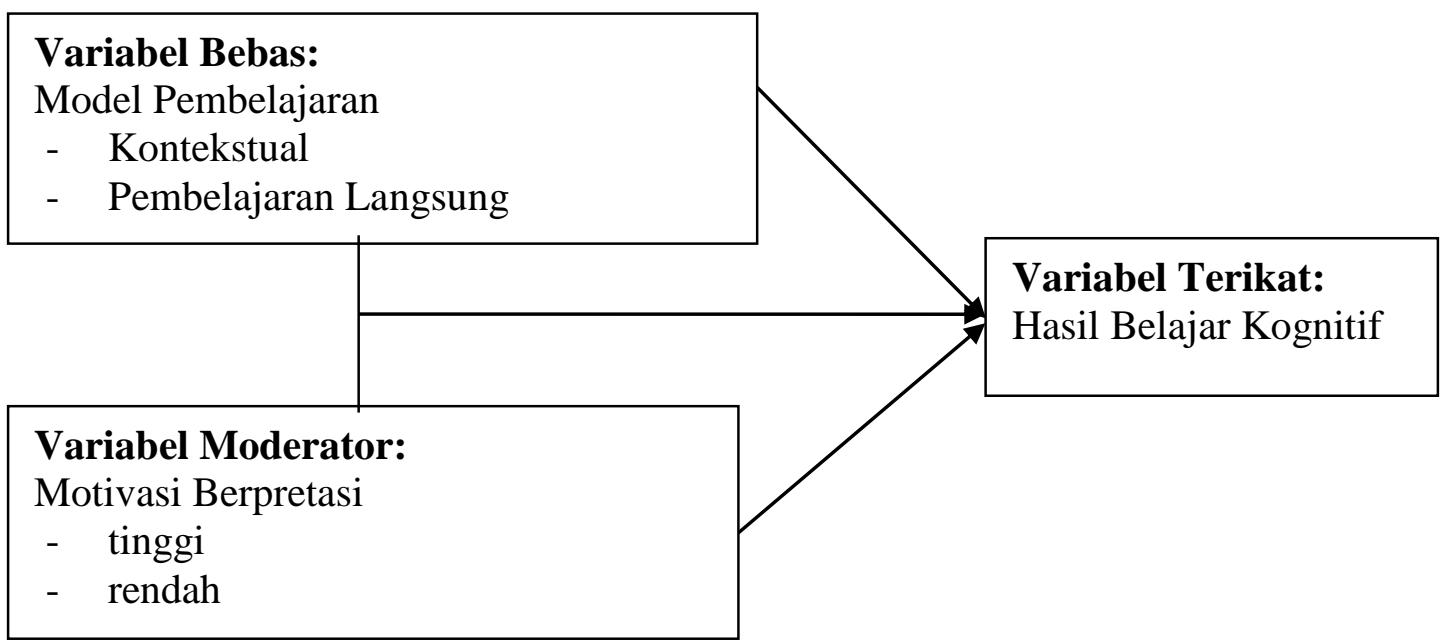

Gambar 2 Hubungan antar Variabel.

Keterangan: $\longrightarrow$ arah pengaruh

Untuk mengumpulkan data dalam penelitian ini digunakan instrumen tes hasil belajar kognitif dan instrumen motivasi berprestasi. Sebelum instrumen tersebut digunakan untuk mengumpulkan data, maka diuji coba dulu guna mendapatkan instrumen penelitian yang memenuhi standar validitas dan reliabilitas. Uji coba instrumen penelitian, dilakukan kepada 71 orang siswa dari 
kelas XI TKR 1 dan TKR 2 semester 3 SMK Negeri 2 Kupang. Kedua kelas tersebut dipilih dengan pertimbangan, karena kelas tersebut telah lulus menempuh pelajaran sepeda motor. Untuk mengetahui validitas item kedua instrumen tersebut, digunakan analisis korelasi Product Moment (Sugiyono, 2011). Suatu item soal dikatakan valid apabila $r_{\text {hitung }}>r_{\text {tabel }}(5 \%)$. Karena instrumen ini diuji-cobakan pada 71 responden maka $r_{\text {tabel }}(5 \%)=0,235$. Untuk mengetahui reliablitas instrumen motivasi berprestasi pada penelitian ini menggunakan analisis Alpha Cronbach, karena skor pada alternatif jawaban berupa rentangan 1 sampai 5. Instrumen motivasi berprestasi dikatakan reliabel, menurut Sufren \& Natanael (2013) adalah apabila koefisien Alpha Cronbach minimal adalah 0,6. Untuk mengetahui reliabilitas instrumen tes, digunakan analisis KR 20, karena soal pilihan ganda memiliki alternatif jawaban 1 jika benar dan 0 jika salah. Suatu item soal dikatakan reliabel apabila $\mathrm{r}_{\text {hitung }}>\mathrm{r}_{\text {tabel }}(5 \%)$. Hasil Uji coba instrumen motivasi berprestasi, dihasilkan jumlah item yang valid dan reliabel 14 item dari sebelumnya 15 item. Untuk instrumen tes hasil belajar kognitif, dihasilkan jumlah item yang valid dan reliabel 39 item dari sebelumnya 47 item.

Sebelum pelaksanaan eksperimen, kedua kelompok subjek penelitian diberikan pretest dan mengisi instrumen motivasi berprestasi. Hasil pretest, sebelum dianalisis dilakukan uji normalitas dan homogenitas. Setelah data tersebut normal dan homogen baru dilakukan analisis uji t, untuk mengetahui ada tidaknya perbedaan antara kedua kelompok subjek penelitian.

Pelaksanaan eksperimen dilaksanakan dalam 10 kali pertemuan pembelajaran, baik untuk kelas X TKR 1 dengan model pembelajaran kontekstual maupun kelas X TKR 2 dengan model pembelajaran langsung. Rangkaian pelaksanaan ekseperimen dan pengumpulan data dalam penelitian ini dirangkum pada tabel 2.

Data yang dikumpulkan dalam penelitian ini berupa skor pretest, skor motivasi berprestasi, dan skor postest. Sebelum data dianalisis dengan ANOVA, terlebih dahulu dilakukan uji persyaratan analisis. Uji persyaratan analisis yaitu, uji normalitas sebaran data dan uji homogenitas varians. Setelah data penelitian dinyatakan normal dan homogen, baru dilanjutkan dengan analisis deskriptif dan ANOVA (Analysis of Variance) 2 jalur pada taraf signifikansi 5\%. Untuk 
melakukan semua analisis dalam penelitian ini, diolah dengan bantuan komputer program SPSS for windows versi 17.0.

Tabel 2. Prosedur Pelaksanaan Ekseperimen dan Pengumpulan Data

\begin{tabular}{|c|c|c|c|c|c|c|c|c|c|c|c|c|}
\hline \multicolumn{13}{|c|}{ Pelaksanaan Kegiatan Pembelajaran Kelas Eksperimen Dan Kelas Kontrol } \\
\hline & & 2 & 3 & 4 & 5 & 6 & 7 & 8 & 9 & 10 & 11 & 12 \\
\hline \multirow{2}{*}{$\begin{array}{l}\text { Instrumen } \\
\text { Berprestasi }\end{array}$} & Motivasi & K & K & $\mathrm{K}$ & $\mathrm{K}$ & K & $\mathrm{K}$ & K & K & $\mathrm{K}$ & $\mathrm{K}$ & Pos \\
\hline & Prete & PL & PL & PL & PL & PL & PL & PL & PL & PL & PL & test \\
\hline
\end{tabular}

Keterangan: K: Kelas dengan model pembelajaran kontekstual

PL : Kelas dengan model pembelajaran langsung

\section{HASIL DAN PEMBAHASAN}

Dari hasil penelitian didapatkan sebaran subjek penelitian berdasarkan model pembelajaran dan motivasi berprestasi dalam bentuk tabulasi silang (crosstabs), adalah sebagai berikut.

Tabel 3. Sebaran Subjek Penelitian Berdasarkan Model Pembelajaran dan Motivasi Berprestasi.

\begin{tabular}{|c|c|c|c|c|}
\hline & & \multicolumn{2}{|c|}{ Model Pembelajaran } & \multirow[b]{2}{*}{ Total } \\
\hline & & Kontekstual & $\begin{array}{c}\text { Pembelajaran } \\
\text { Langsung }\end{array}$ & \\
\hline \multirow{2}{*}{ Motivasi Berprestasi } & Rendah & $\begin{array}{c}18 \text { siswa } \\
23,38 \%\end{array}$ & $\begin{array}{c}19 \text { siswa } \\
24,68 \%\end{array}$ & $\begin{array}{c}37 \text { siswa } \\
48,06 \%\end{array}$ \\
\hline & Tinggi & $\begin{array}{l}20 \text { siswa } \\
25,97 \%\end{array}$ & $\begin{array}{l}20 \text { siswa } \\
25,97 \%\end{array}$ & $\begin{array}{c}40 \text { siswa } \\
51,94 \%\end{array}$ \\
\hline \multicolumn{2}{|l|}{ Total } & $\begin{array}{l}38 \text { siswa } \\
49,35 \%\end{array}$ & $\begin{array}{l}39 \text { siswa } \\
50,65 \%\end{array}$ & $\begin{array}{c}77 \text { siswa } \\
100 \%\end{array}$ \\
\hline
\end{tabular}

Sebelum perlakuan eksperimen dimulai maka kedua kelompok subjek penelitian diberikan pretest. Berdasarkan hasil pretest, diketahui bahwa mean atau rerata hasil belajar kelompok siswa yang diajar dengan model pembelajaran kontekstual adalah 39,53 dan $\mathrm{SD}=6,644$, sedangkan kelompok siswa yang diajar dengan model pembelajaran langsung adalah 40,23 dan $\mathrm{SD}=6,028$. Untuk mengetahui apakah kedua kelompok tersebut berbeda secara signifikan atau tidak, maka dilakukan analisis statistik uji t dua sampel independen.

Sebelum dilakukan uji t, data tersebut perlu dilakukan uji normalitas dan uji homogenitas sebagai persyaratan untuk dapat dianalisis uji t. Hasil uji normalitas dengan uji Kolmogorov-Smirnov, didapatkan angka signifikansi (SIG) Pembelajaran Kontekstual 0.130 dan Pembelajaran langsung 0,200. Hasil ini lebih besar dari 0,05 , sehingga kedua kelompok data pretest dinyatakan berdistribusi 
normal. Hasil uji dengan Levene's Test dengan dasar mean, didapatkan angka (SIG) 0,185>0,05, sehingga data pretest dinyatakan homogen Setelah diketahui data pretest berdistribusi normal dan mempunyai varians yang homogen, dilanjutkan dengan analisis uji t dua sampel independen. Dari hasil uji t dua sampel independen, menunjukan nilai signifikansi (SIG) untuk hasil belajar kognitif sepeda motor (pretest) antara kelompok model pembelajaran kontekstual dan kelompok model pembelajaran langsung sebesar 0,627 ( $\mathrm{p}>0,05)$. Hal ini berarti bahwa hasil belajar kognitif (pretest) antara kelompok pembelajaran kontekstual dan kelompok pembelajaran langsung menunjukan tidak ada perbedaan yang signifikan ( $p>0,05)$. Dengan demikian dapat dimaknai bahwa kemampuan awal kedua kelompok adalah setara. Dari hasil pengumpulan data didapatkan data sebagai berikut yang ditabulasikan dalam tabel berikut ini.

Tabel 4. Ringkasan Analisis Deskriptif Data Hasil Penelitian

\begin{tabular}{llllll}
\hline \multirow{2}{*}{ Hasil Belajar } & \multirow{2}{*}{ Model Pembelajaran } & $\begin{array}{c}\text { Motivasi } \\
\text { Berprestasi }\end{array}$ & Mean & Std. Deviation & N \\
\hline \multirow{2}{*}{ Kognitif } & Kontekstual & Rendah & 75.0556 & 9.96153 & 18 \\
& & Tinggi & 80.7000 & 7.96770 & 20 \\
& Total & 78.0263 & 9.29250 & 38 \\
& Pembelajaran & Rendah & 68.2105 & 7.26926 & 19 \\
& Langsung & Tinggi & 74.6000 & 6.51638 & 20 \\
& Total & 71.4872 & 7.53194 & 39 \\
& Total & Rendah & 71.5405 & 9.23639 & 37 \\
& Tinggi & 77.6500 & 7.82026 & 40 \\
& Total & 74.7143 & 9.01294 & 77 \\
\hline
\end{tabular}

Langkah selanjutnya adalah melakukan uji persyaratan analisis, yaitu melakukan uji normalitas dan homogenitas data penelitian. Hasil uji normalitas data dengan normal probability menggunakan uji Kolmogrov-Smirnov untuk variabel hasil belajar kognitif sebesar 0,172. Nilai signifikansi hasil uji Kolmogrov-Smirnov pada variable hasil belajar kognitif berada jauh di atas 0,05, sehingga dapat dinyatakan bahwa data penelitian berdistribusi normal. Berdasarkan hasil uji homogenitas varians dengan uji Levene's Test untuk hasil belajar kognitif sebesar 0,060. Nilai signifikansi hasil uji Levene's Test pada variable hasil belajar kognitif berada jauh di atas 0,05 , yang berarti matrik varians variabel tersebut adalah homogen. Setelah data penelitian didapatkan normal dan homogen, selanjutnya 
data dianalisis menggunakan ANOVA. Dari hasil pengujian data dengan analisis ANOVA, didapatkan hasil sebagai berikut.

Tabel 5. Hasil Analisis ANOVA Pervariabel (Tests of Between-Subjects Effects) Dependent Variable:HBKognitif

\begin{tabular}{|c|c|c|c|c|c|}
\hline Source & $\begin{array}{l}\text { Type III Sum of } \\
\text { Squares }\end{array}$ & $\mathrm{df}$ & Mean Square & $\mathrm{F}$ & Sig. \\
\hline Corrected Model & $1522.612^{\mathrm{a}}$ & 3 & 507.537 & 7.966 & .000 \\
\hline Intercept & 428180.663 & 1 & 428180.663 & 6720.383 & .000 \\
\hline ModelPemblj & 804.919 & 1 & 804.919 & 12.633 & .001 \\
\hline MotivasiBerpr & 695.601 & 1 & 695.601 & 10.918 & .001 \\
\hline $\begin{array}{l}\text { ModelPemblj * } \\
\text { MotivasiBerpr }\end{array}$ & 2.666 & 1 & 2.666 & .042 & .838 \\
\hline Error & 4651.102 & 73 & 63.714 & & \\
\hline Total & 436005.000 & 77 & & & \\
\hline Corrected Total & 6173.714 & 76 & & & \\
\hline
\end{tabular}

a. R Squared $=, 247$ (Adjusted R Squared $=, 216$ )

Dari hasil analisis dengan ANOVA maka dapat disimpulkan sebagai berikut: (1) untuk pengaruh model pembelajaran terhadap hasil belajar kognitif didapatkan F hitung sebesar 12,633 dengan nilai signifikansi probability 0,001. Nilai signifikansi tersebut masih jauh di bawah 0,05. Dengan demikian, dapat disimpulkan bahwa ada perbedaan hasil belajar kognitif yang signifikan antara siswa yang diajar dengan model pembelajaran kontekstual dan pembelajaran langsung, (2) untuk pengaruh motivasi berprestasi terhadap hasil belajar kognitif didapatkan nilai $\mathrm{F}$ hitung sebesar 10,918 dengan nilai signifikansi probability 0,001. Nilai signifikansi tersebut masih jauh di bawah 0,05. Dengan demikian, dapat dikatakan ada perbedaan hasil belajar kognitif yang signifikan antara siswa dengan motivasi berprestasi tinggi dan siswa dengan motivasi berprestasi rendah, (3) dari hasil analisis ANOVA terhadap interaksi antara model pembelajaran dan motivasi berprestasi pada hasil belajar kognitif didapatkan nilai $\mathrm{F}$ hitung 0,042 dan nilai signifikansi probability 0,838 . Nilai signifikansi tersebut berada jauh di atas 0,05. Dengan demikian, dapat disimpulkan bahwa tidak ada interaksi antara model pembelajaran dan motivasi berprestasi pada hasil belajar kognitif.

\section{Pengaruh Model Pembelajaran terhadap Hasil Belajar Kognitif}

Jika ditinjau dari skor rerata (mean) hasil belajar kognitif, untuk kelompok siswa pada penerapan model pembelajaran kontekstual $(78,03)$ lebih tinggi 
dibandingkan dengan skor rerata kelompok siswa pada model pembelajaran langsung $(71,48)$. Hal ini berarti, penerapan model pembelajaran kontekstual memberikan pengaruh yang lebih baik terhadap perolehan hasil belajar kognitif dibandingkan dengan penerapan model pembelajaran langsung. Dari hasil penelitian juga terlihat, pada pembelajaran kontekstual membuat siswa lebih tertarik untuk belajar, baik secara individu maupun secara berkelompok untuk mencari solusi dari pemecahan masalah yang dibahas. Lebih jauh lagi, kondisi ini membuat kemampuan pemecahan masalah siswa dapat meningkat, sebab siswa mengidentifikasi secara langsung seluruh data yang relevan dengan situasi yang ada, dan berusaha untuk memberikan solusinya. Selain itu, pada pembelajaran kontekstual memberikan kondisi yang membuat siswa lebih termotivasi dalam belajar, sehingga selalu bersemangat dan mengumpulkan tugas tepat pada waktunya. Dengan demikian, model pembelajaran yang diterapkan pada suatu pembelajaran perlu mendapat perhatian,karena mempunyai pengaruh positif terhadap hasil belajar siswa, walaupun dengan bahan pelajaran dan fasilitas yang sama.

Penerapan model pembelajaran kontekstual pada suatu pembelajaran, memberikan pengaruh yang positif terhadap hasil belajar siswa. Hal ini sejalan dengan penelitian Danielson, et al. (2003) yang menyatakan, dengan pembelajaran kontekstual maka kemampuan pemecahan masalah siswa dapat meningkat, karena siswa terbiasa dihadapkan dengan masalah-masalah pembelajaran dan solusinya. Selanjutnya, penelitian Smith (2010) menyatakan, beberapa faktor dalam pembelajaran kontekstual yang dapat berpengaruh positif terhadap perolehan hasil belajar lebih tinggi, adalah: (1) penggunaan model pembelajaran kontekstual dapat meningkatkan lama siswa dalam belajar. Hal ini disebabkan, siswa belajar materi dalam konteks yang nyata, sehingga memperkuat memori siswa, (2) siswa lebih termotivasi untuk belajar ketika mengetahui relevansinya dalam kehidupan nyata, terutama bagi siswa yang merasa bosan bersekolah. Selanjutnya, beberapa keunggulan dalam pembelajaran kontekstual dibandingkan dengan pembelajaran konvesional, juga dinyatakan dari hasil penelitiannya Suparman (2013), yaitu: (1) kelompok siswa yang dikenai pembelajaran kontekstual secara signifikan mencapai prestasi menulis yang lebih baik dari pada yang diajarkan dengan 
pendekatan konvensional, (2) siswa dengan motivasi berprestasi tinggi dan rendah yang dikenai dengan pembelajaran kontekstual secara signifikan mendapat prestasi yang lebih tinggi daripada mereka yang dikenai dengan pembelajaran konvensional. Dengan demikian dapat disimpulkan pembelajaran kontekstual mempunyai pengaruh yang signifikan terhadap hasil belajar kognitif dibandingkan dengan pembelajaran langsung.

\section{Pengaruh Motivasi Berprestasi terhadap Hasil Belajar Kognitif}

Jika ditinjau dari skor rerata (mean) hasil belajar kognitif, kelompok siswa yang mempunyai motivasi berpretasi tinggi adalah (77,65), lebih tinggi dibandingkan dengan skor rerata kelompok siswa yang mempunyai motivasi berprestasi rendah $(71,54)$. Hal ini berarti bahwa motivasi berprestasi tinggi mempunyai pengaruh yang lebih baik terhadap perolehan hasil belajar kognitif dibandingkan dengan motivasi berprestasi rendah. Motivasi berprestasi memiliki peran penting pada diri pebelajar dalam proses pembelajaran, yaitu memberikan dampak terhadap hasil belajar sebagai wujud akhir dari proses pembelajaran. Seseorang yang memiliki motivasi berprestasi akan mendorong dirinya untuk melakukan sesuatu yang lebih baik dari pada orang lain yang tidak memiliki motivasi berprestasi. Pentingnya motivasi berprestasi dalam konteks kegiatan pembelajaran adalah akan mendorong pebelajar cenderung membuat pilihan pada tindakan yang realistis, yang dapat menilai kemampuannya terhadap tugas-tugas yang akan dikerjakan. Pada kegiatan pembelajaran, guru dan pebelajar memiliki peran yang berbeda. Guru berperan sebagai motivator dan fasilitator pembelajaran. Pebelajar berperan sebagai pihak yang harus memotivasi dirinya agar dapat mencapai target yang diinginkannya. Pebelajar yang memiliki motivasi berprestasi akan memandu dirinya untuk bertanggung jawab atas tugas yang harus diselesaikannya., sehingga akan bekerja secara bersungguh-sungguh menyelesaikan tugas-tugas yang harus dikerjakannya.

Selain itu, pebelajar yang mempunyai motivasi berprestasi tinggi akan berusaha membedakan dirinya dengan orang lain yang tidak memilikinya. Di mana, pebelajar tersebut akan tertantang untuk menyelesaikan setiap tugas tepat pada waktunya dan berusaha untuk mencari solusi setiap permasalahan pembelajaran 
yang dihadapinya. Kondisi yang berbeda (sebaliknya), terjadi pada diri pebelajar yang kurang memiliki motivasi berprestasi, yang cenderung lambat dan tidak bersemangat dalam mengerjakan tugas-tugasnya. Apalagi bila menghadapi permasalahan pembelajaran yang berat, maka pebelajar tersebut cenderung mudah patah semangat dan putus asa. Dari sinilah, maka akan diperoleh hasil akhir pembelajaran yang berbeda, di mana perolehan hasil belajar pebelajar dengan motivasi berprestasi tinggi lebih unggul dari pada pebelajar dengan motivasi berprestasi rendah.

Hasil penelitian ini sejalan dengan hasil penelitianya Knowles \& Kerkman (2007) yang menyimpulkan bahwa, pada pembelajaran model online diketahui adanya peran penting dari motivasi berprestasi. Siswa yang memiliki motivasi berprestasi tinggi cenderung bersemangat dalam menyelesaikan tugasnya tepat pada waktu yang telah ditentukan. Selanjutnya, siswa yang tidak memiliki motivasi berprestasi, ada kecenderungan kurang bersemangat dalam menyelesaikan tugastugas pembelajaran. Pada umumnya, siswa dalam kategori ini cenderung lambat bahkan lalai dalam menyelesaikan tugas-tugasnya. Hal ini berdampak pada hasil belajar, sebagai akumulasi terhadap penilaian kinerja mereka secara online. Selanjutnya, Onete et al. (2012), dari hasil penelitiannya menyimpulkan, motivasi berprestasi memiliki pengaruh yang signifikan terhadap kinerja akademik mahasiswa pendidikan. Di mana, dari hasil studi tersebut diperoleh fakta bahwa motivasi berprestasi bagi seseorang merupakan faktor pendorong untuk belajar. Motivasi berprestasi berfungsi untuk memperkuat keinginan yang dimiliki, sehingga apa yang ingin dicapai dapat terwujud. Hal ini sejalan dengan penelitiannya Gupta et al. (2012), yang menemukan bahwa motivasi berprestasi memainkan peran penting dalam menentukan prestasi akademik mereka. Kelompok siswa dengan motivasi berprestasi tinggi menunjukan prestasi yang lebih unggul dari pada siswa dengan motivasi berprestasi rendah. Oleh karena itu, siswa yang termasuk kelompok motivasi berprestasi rendah harus disediakan fasilitas belajar yang tepat dan didorong agar prestasi akademik mereka juga meningkat. Siswa tersebut harus diberikan motivasi yang tepat oleh sekolah dan orang tua. Dengan demikian dapat disimpulkan motivasi berprestasi tinggi 
mempunyai pengaruh yang signifikan terhadap hasil belajar kognitif dibandingkan motivasi berprestasi rendah.

\section{Interaksi Model Pembelajaran dan Motivasi Berprestasi pada Hasil Belajar Kognitif}

Berdasarkan hasil uji ANOVA dari penelitian ini menunjukan bahwa: tidak ada interaksi antara model pembelajaran dan motivasi berprestasi pada hasil belajar kognitif pelajaran sepeda motor pada siswa kelas X TKR SMK Negeri 2 Kupang. Kondisi ini, dapat dilihat dari gambaran pola interaksi model pembelajaran dan motivasi berprestasi seperti pada gambar 3 .

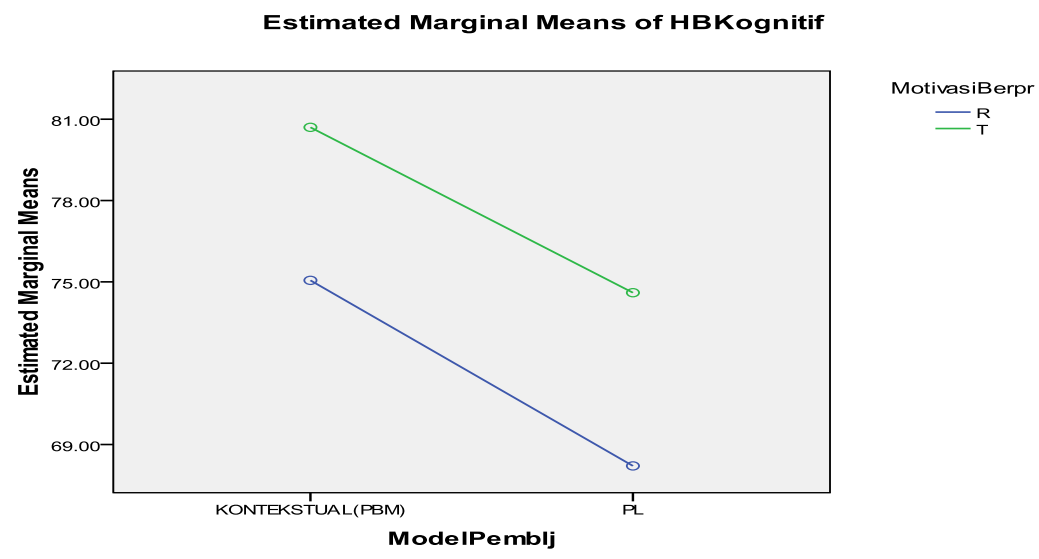

Gambar 3. Pola interaksi antara model pembelajaran dengan motivasi berprestasi pada hasil belajar kognitif

Berdasarkan hasil uraian di atas, dapat diketahui bahwa tidak terdapat interaksi antara model pembelajaran dan motivasi berprestasi pada hasil belajar kognitif dan keterampilan motorik. Ketiadaan interaksi menunjukkan jika variabel bebas (model pembelajaran) dan variabel moderator (motivasi berprestasi) lebih membawa pengaruh-pengaruh terpisah yang signifikan terhadap variabel terikat, atau masing-masing variabel bebas mempunyai pengaruh utama yang signifikan. Jika model pembelajaran dan motivasi berprestasi berinteraksi, namun tidak mempunyai pengaruh yang signifikan pada hasil belajar kognitif, kondisi ini mengindikasikan variabel model pembelajaran dan variabel motivasi berprestasi memberikan pengaruh yang sama kuat. Hal ini dikemukan oleh Hair et al. (1995) bahwa istilah interaksi merupakan pengaruh gabungan (joint effect) dari dua perlakuan, dan pengaruh tersebut harus diuji terlebih dahulu. Jika pengaruh 
interaksi tidak signifikan, maka variabel bebas mempunyai pengaruh yang independen atau berdiri sendiri. Independen dalam desain faktorial berarti bahwa pengaruh dari satu perlakuan adalah sama kuat dengan perlakuan lainnya.

Tidak terjadinya interaksi antara model pembelajaran (kontekstual dan PL) dan motivasi berprestasi pada hasil belajar kognitif dan keterampilan motorik, dikarenakan kuatnya pengaruh masing-masing variabel model pembelajaran dan motivasi berprestasi terhadap variabel hasil belajar. Hal ini sejalan dengan apa yang dikemukan oleh Hair (1995) dan Kerlinger et al (2000), yang menyebutkan tidak terjadinya interaksi disebabkan jika dua variabel bebas atau lebih membawa pengaruh-pengaruh secara terpisah yang sangat kuat (signifikan) terhadap variabel terikat. Pengaruh-pengaruh terpisah dari variabel bebas ini disebut pengaruh utama (main effect). Dan temuan dalam penelitian ini juga sejalan dengan beberapa penelitian lainnya dari Tan (2011); Panitz (2011); yang menyimpulkan adanya pengaruh utama yang kuat dari variabel bebas dan variabel moderator terhadap variabel terikat, sehingga melemahkan interaksi yang ada. Artinya, model pembelajaran tidak memiliki interaksi yang kuat (signifikan) dengan motivasi berprestasi terhadap perolehan hasil belajar siswa. Dengan kata lain, tidak adanya interaksi tersebut karena tidak dominannya pengaruh model pembelajaran dari motivasi berprestasi terhadap hasil belajar, atau sebaliknya pengaruh motivasi berprestasi tidak lebih dominan dari model pembelajaran terhadap hasil belajar.

\section{KESIMPULAN}

1. Ada perbedaan hasil belajar kognitif yang signifikan pada pelajaran sepeda motor antara kelompok siswa yang diberi perlakuan dengan model pembelajaran kontekstual dan kelompok siswa yang diberi perlakuan dengan model pembelajaran langsung.

2. Ada perbedaan hasil belajar kognitif yang signifikan pada pelajaran sepeda motor antara kelompok siswa yang mempunyai motivasi berprestasi tinggi dan kelompok siswa yang mempunyai motivasi berprestasi rendah.

3. Tidak ada interaksi antara model pembelajaran dan motivasi berprestasi terhadap hasil belajar kognitif pada pelajaran sepeda motor 


\section{DAFTAR PUSTAKA}

Ahmadi, I.K., Amri, S. \& Elisah, T. (2011). Strategi Pembelajaran Sekolah Terpadu. Jakarta: Prestasi Pustaka Publisher.

Asyto, B.P. (2013). Hubungan Pemberian Tugas dengan Hasil Belajar Siswa pada Mata Pelajaran Teknik Sepeda Motor di SMK N 1 Tarusan. Automotive Engineering Education Journals. Vol.1 No.1 (2013).

Banuarli, A. (2012). Perbedaan Hasil Belajar Dengan Metode Pembelajaran Kooperatif Tipe Teams Games Tournament (Tgt) dan Konvensional dalam Mata Pelajaran Dasar Otomotif Sepeda Motor pada Siswa Kelas X Jurusan Sepeda Motor di SMK Muhammadiyah 1 Bambanglipuro. Skripsi. Yogyakarta: Fakultas Teknik UNY.

Bern, R.G. \& Erickson, P.M. (2001). Contextual Teaching and Learning: Preparing Students for the New Economy. The Highlight Zone: Research (C) Work No. http://www.nccte.com/publications/infosynthesis/index.asp\#HZ. diakses: 15 April 2012.

Danielson, J.A., Bander, H.S., Milss, E.M., Vwermeer, P.J. \& Lockee, B.B. (2003). A Tool for Helping Veterinary Lear Diagnostic Problem Solving. Education Technology Research and Development, 51(3): 63-81.

Efendi, M. (2009). Kurikulum dan Pembelajaran: Pengantar ke Arah Pemahaman KBK, KTSP, dan SBI. Malang: FIP Universitas Negeri Malang.

Fong Ma, A.K., O’Toole, J. \& Keppell, M. (2008). An Investigation of Student Teachers' Attitudes to the Use of Media Triggered Problem Based Learning, Australasian Journal of Educational Technology. 24(3),311-325

Frank, M. \& Barzilai, A. (2006). Project-Based Technology: Instructional Strutegy for Developing Tecnological Literacy, Journal of Technology Education. 18(1): 39-53.

Ghozali, I. (2009). Aplikasi Analisis Multivariat dengan Program SPSS. Semarang: Badan Penerbit Universitas Diponegoro.

Gupta, M., Devi, M., \& Pasrija, P. (2012). Achievement Motivation: a Major Factor in Determining Academic Achievement. Asian Journal of Multidimensional Research. 1(3): 131-145.

Hair, J.F., Anderson, R.E., Tatham, R.L. \& Balck, W.C. (1995). Multivariate Data Analysis with Reading. Fourth Edition. New Jersey: Prentice-Hall, Inc.

Hitipeuw, I. (2009). Belajar dan Pembelajaran. Malang: FIP Universitas Negeri Malang.

Johnson, E.B. (2002). Contextual Teaching and Learning. California: Corwin Press, Inc.

Kelley, T. \& Kelam, N. (2009). A Theoretical Framework to Guide the ReEngineering of Technology Education, Journal of Technology Education. 20(2): 37-49 
Kerlinger, F.N. \& Lee, H.B. (2000). Foundations of Behavioral Research. Fourth Edition. California: Wadsworth Publishing Company.

Knowles, E. \& Kerkman, D. (2007). An Investigation of Students Attitude and Achievement Motivation toward Online Learning. Student Motivation. 2: 70-80.

Komalasari, K. (2012). The Living Value-Based Contextual Learning to Develop the Students' Character. Journal of Social Sciences, 8(2): 246-251.

Krathwohl, D.E., Bloom, B.E. \& Masia, B.B. (1964). Taxonomy of Educational Objects, The Classification of Educational Goals, Handbook II: Affective Domain. Longmans.

Mukhadis, A. (2003). Pengorganisasian Isi Pembelajaran Tipe Prosedural (Kajian empirik pada Latar Sekolah Menengah Kejuruan Rumpun Teknologi). Malang: UM Press.

Nuh, M. (2011). SMK, Mempersiapkan Siswa Masuk Dunia Kerja. Koran Jakarta 18 Februari 2011. Jakarta.

Onete, O.U., Edet, P.B., Udey, F.U. \& Ogbor, B.P. (2012). Academic Performance: a Function of Achievement Motivation Among Education Students of Cross River University of Technology, Calabar. Review of Higher Education in Africa. 4(): 63-83

Panitz, T. (2011). Benefits of Cooperative Learning in Relation to Student Motivation. (online). http://home.capecod.net/ tpanitz/tedsarticles/motivation.html. diakses 14 April 2014.

Ridwan. (2008). Pengaruh Model Pembelajaran (Kontekstual vs Konvensional) dan Gaya Belajar terhadap Pemahaman Konsep, Kemampuan Psikomotor dan Pemecahan Masalah pada Mahasiswa Teknik Elektro Fakultas Teknik Universitas Negeri Padang (Disertasi). Malang: Pasca Sarjana Universitas Negeri Malang.

Smith, B.P. (2010). Instructional Strategies in Family and Consumer Sciences: Implementing the Contextual Teaching and Learning Pedagogical Model. Journal of Family \& Consumer Sciences Education. 28(1): 23-38.

Sufren \& Natanael, Y. (2013). Mahir Menggunakan SPSS Secara Otodidak. Jakarta: PT Elex Media Komputindo

Sugiyono. (2011). Statistika Untuk Penelitian. Bandung: Alfabeta

Sumarna. S. (2004). Peningkatan Pendidikan MIPA dalam Master Plan Pendidikan Indonesia 2005-2009. Makalah disampaikan dalam Seminar Nasional Penelitian, Pendidikan, dan Penerapan MIPA tanggal 2 Agustus 2004, kerjasama FMIPA UNY, Ditjen Dikti Depdiknas, dan IMSTEP-JICA

Suparman, L., Marhaeni, A.A.I.N. \& Dantes, N. (2013). The Effect of Contextual Teaching and Learning Approach upon Students' Writing Competency for the Tenth Grade Students of SMA N 1 Keruak in the Academic Year 20122013. e-Journal Program Pascasarjana Universitas Pendidikan Ganesha Program Studi Pendidikan Bahasa Inggris (Volume 1 Tahun 2013) 
Tan, I.G.C. (2011). Effects of Group Investigation on Academic Achievement and Motivation of High and Low Ability Students in Singapore Secondary Schools. (online). http://www.iasce.net/publications.html. diakses 10 April 2014.

Tuckman, B.W. (1999). Conducting Educational Research. Fifth Edition. Orlando: EarlMcpeek Publisher 